\title{
Theoretical and Experimental Substantiation for Applicability of a Damping Layer in a Foundation Slab Placed on Soil Bed
}

\author{
Nikita Kiselev ${ }^{1}$, Yakov Pronozin ${ }^{1}$, Maxim Stepanov ${ }^{1}$, Leonid Bartolomey, ${ }^{1,}$, Dietmar \\ Keck $^{1}$ \\ ${ }^{1}$ Industrial University of Tyumen, 625001, Volodarskogo str., 38, Tyumen, Russia
}

\begin{abstract}
Authors present the results of studies of innovative foundation structure. The idea of how to increase the operational quality of foundations and reduce the costs due to rational loading of the soil bed is numerically simulated. It is shown that the bending moment in the foundation slab depends on uneven settlements of the soil bed. It is proposed to stabilize the deformable soil bed by the damping layer placed under the slab footing in the zones with minor settlements. Considered is the concept of the damping layer in the foundation slab placed on the soil bed (DLS). The in-situ test for DLS-clayey bed interaction is described. Given are the results obtained after the experiments for DLS performance. The result of DLS implementation in designing the foundation of the 22storeyed block of flats is considered. The expediency of DLS in comparison to standard foundations is presented.
\end{abstract}

\section{Introduction}

The last decade has witnessed a steady growth of residential construction in Russia. In order to create conditions for residential construction and provide population with affordable and comfortable flats, the state program "Residential Construction Development" optimized for 2014-2016 has been launched in Tyumen Region; the program aims at erecting economy-class blocks of flats that meet the requirements of energy efficiency and environmental friendliness. Foundation works greatly influence labor and material costs, i.e. the cost of the foundation is $10-20 \%$ from the total cost of the building depending on its structural features. In this regard, applicability of the rational foundations becomes challenging from the point of view of material consumption and technological effectiveness of construction, taking into account sustainability and safety of constructional projects.

Tyumen Region is characterized by complex engineering-geological conditions. As a rule, the soil bed is composed of weak water-saturated floury-clay soils occurring at a considerable stratification depth; they possess low strength and are highly deformable in external loading $[1,2]$. The traditional strip foundations are not applicable for $12 \ldots 15$ -

* Corresponding author: tgasu.bartolomey.leonid@mail.ru 
storeyed buildings because of low design strength of the soil bed, weak structural bond between separate strips and their response to uneven settlements. Foundation slabs are characterized by the considerable compressed depth and hence, the excessive design settlements and high materials consumption. Therefore, the idea to expand possible application of shallow foundations due to specified rational loading of the soil bed was formulated $[3,4]$.

\section{Concept for a damping layer in a foundation slab placed on soil bed (DLS)}

As is known from "classical" soil mechanics, when a flexible slab is uniformly loaded, the settlement in the center 1.24-1.57 times exceeds the settlements in the edges [5]. As for sustainability of buildings and structures, the value of settlement unevenness is more important than its average absolute value, since it is unevenness that leads to excessive stresses and strains in the slab and above ground structures, and their operational qualities considerably decrease $[6,7,8]$. Let us consider possible loading of the slab, so that minimum unevenness of soil bed settlements was provided.

Numerical computation done in PLAXIS 2D software revealed the design features of soil bed deformation under the load taking into account different distribution laws (Fig. 1a). Flexible slab $(1=6.0 \mathrm{~m}, \mathrm{t}=0.3 \mathrm{~m}, \mathrm{E}=30000 \mathrm{MPa})$-sandy clay soil bed $(\gamma=18 \mathrm{kN} / \mathrm{m} 3, \mathrm{e}=$ $0.75, \varphi=18^{\circ}, \mathrm{c}=20 \mathrm{kPa}, \mathrm{E}=18 \mathrm{MPa}$ ) interaction was considered using elastic-plastic model of Mohr-Coulomb. The slab flexibility value was equal to 6 after the solution of M.I. Gorbunov-Posadov [5], i.e. the slab was considered to possess finite rigidity. In the first computation the slab was uniformly vertically loaded with the intensity of $100 \mathrm{kPa}$, in the subsequent computations the load was redistributed from the center to the edges $1.0 \mathrm{~m}$ in width, saving its total value. The results obtained showed that in the first loading the slab saddled considerably, and in the third loading unevenness of settlements was close to zero (Fig. 1b), in here, the peak value of the bending moment was up to 8 times lower than in the case of the uniform load (Fig. 1c). In further loading of the edge the slab bent in the center, unevenness of settlements and the bending moment increased. The area of the bending moment diagrams (Fig. 1d) affecting material consumption of the foundation was directly dependent upon the settlement differences; the material consumption was 6 times lower for the $3 \mathrm{~d}$ variant than in the case of the uniform load. Thus, it has been proved that when adapting load distribution over the foundation slab, it is possible to ensure more favorable conditions of its performance. 
a)

a) 1

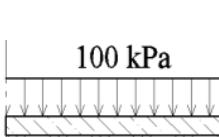

2

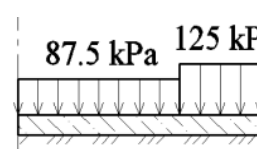

3

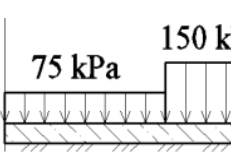

4

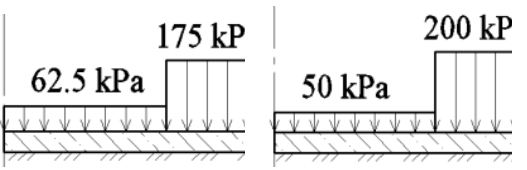

b)
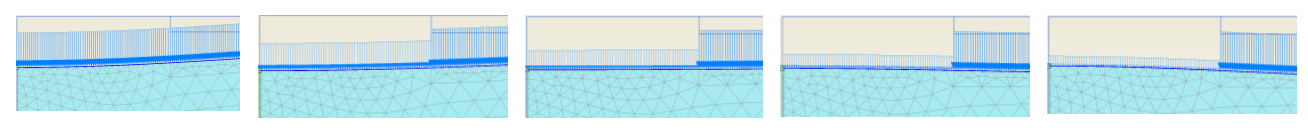

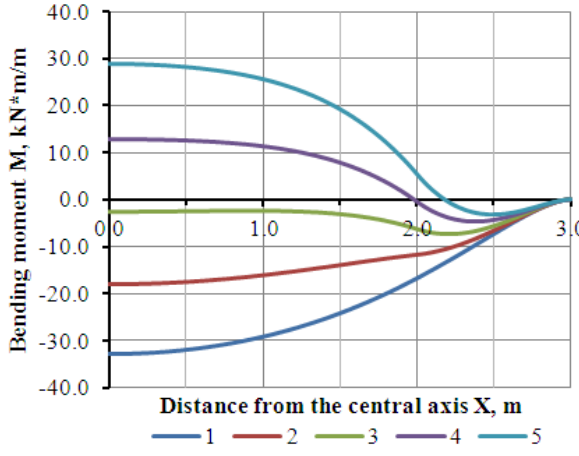

c)

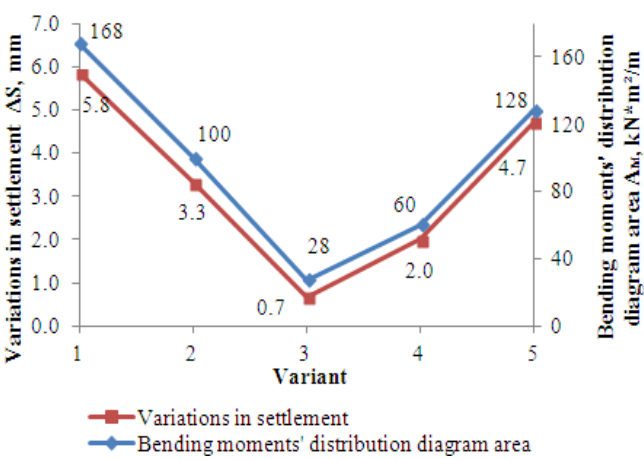

d)

Fig. 1. Plane stress problem with various load distribution on the foundation (variants $1 \ldots 5$ ): a) design diagram; b) strain diagram; c) bending moments in the slab; d) dependency diagram for unevenness of settlements and bending moments' distribution diagram area for different cases of loading

However, loading of the foundation is conditioned by the architectural form of the structure and its technological purpose, i.e. it is "static" and does not offer "plasticity" making it possible to realize the specified loading. The authors $[9,10,11$, etc.] offer to eliminate unevenness of settlements of the foundation slab by correcting soil bed deformability, e.g. by strengthening the soil bed under the center of the slab or weakening it under the slab edges. Taking into account the following hypothesis, let us solve the problem by changing deformability of the soil bed rather than redistribution of the load.

The initial data are given above, but let us introduce the damping layer of $b=1.0 \mathrm{~m}$ in width and $\mathrm{t}=0.2 \mathrm{~m}$ in thickness with the variable modulus of elasticity $-\mathrm{E}=1.0 \ldots 2.5 \mathrm{MPa}$ under the slab edge; in here, the load remains uniform - $100 \mathrm{kPa}$ (Fig. 2). In general, the revealed dependences are analogous to those mentioned above; thus, the damping layer has made it possible to level the settlements of the soil bed and reduce the bending moments in the slab up to 7 times. Thus, it seems possible to achieve the specified technical result by simpler and more constructable method than in the previous example. 


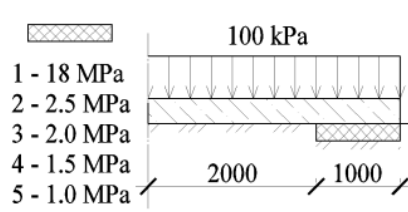

a)

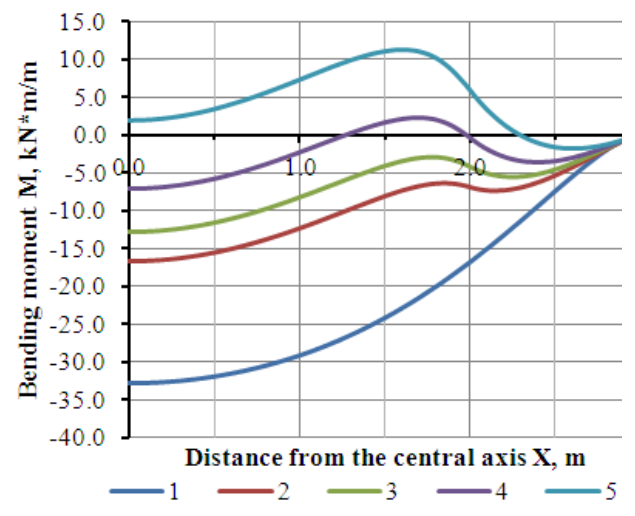

d)

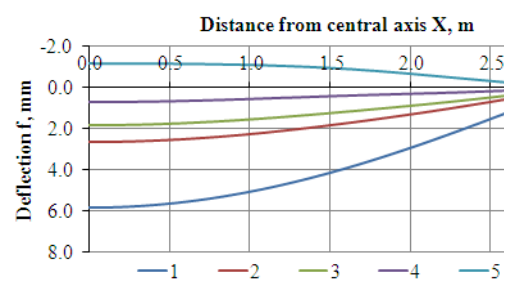

c)

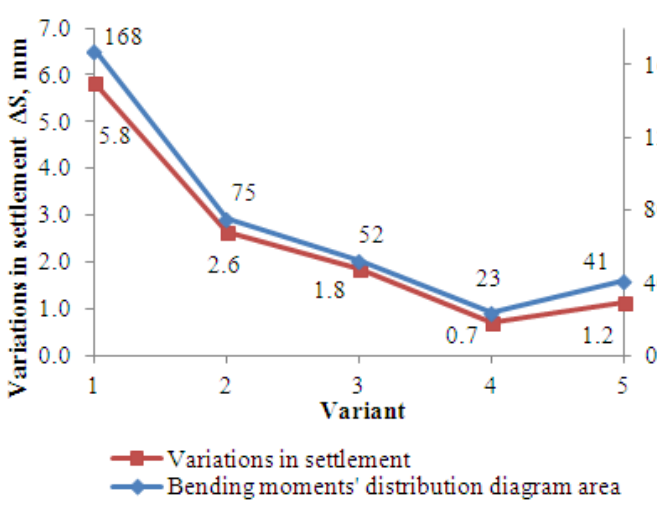

e)

Fig. 2. Plane stress problem with various damping layers under the foundation edge (variants $1 \ldots 5$ ): a) design diagram; b) strain diagram (variant 4); c) deflections in the slab; d)bending moments in the slab; e) dependency diagram of unevenness of settlements and bending moments' distribution diagram area for different cases of loading

A possible way to put this hypothesis into practice is to apply damping layers in slab foundations placed on the soil bed (DLS); this allows the reaction pressures over the slab footing to be rationally distributed proceeding from minimization of stresses in the foundation body or adaptation of the constructional project to specific soil conditions.

The rational use of such foundations is conditioned by the following:

- In case of the flexible slab, e.g. a uniformly loaded foundation of the reservoir, the damping layer in the edges compensates non-uniform compressibility of the soil bed over the foundation footing, decreases deflections and bending moments in the structure. (Fig. 3a).

- In case of the foundation slab of a multistory building, the damping layers in the span zones allow concentrating pressures in the load-bearing axes, unload the span zone and decrease bending moments in the slab (Fig. 3b).

- In case of quite stiff low-compressible covering layers and the underlying thick layer of weak water-saturated soils occurring in the geological structure of the construction site, the decrease of pressures allows reducing the compressible thickness (Fig. 3c) to some extent, the effect on the weak underlying layers, and hence, the settlement of the foundation. 


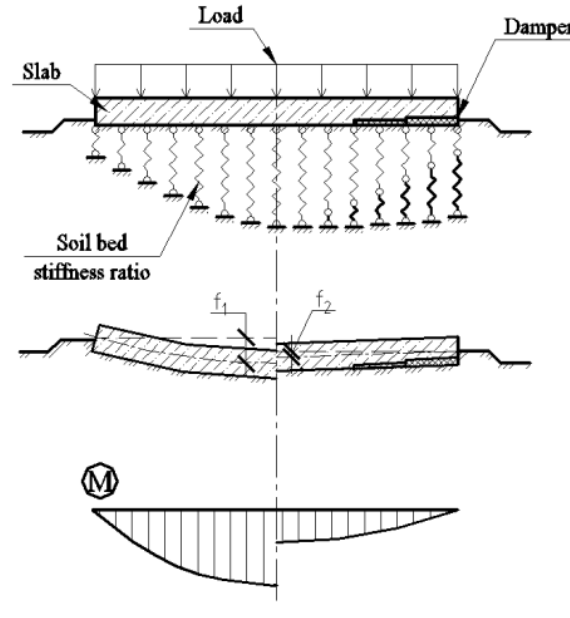

a)
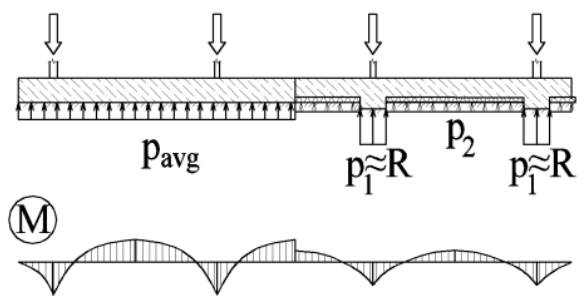

b)

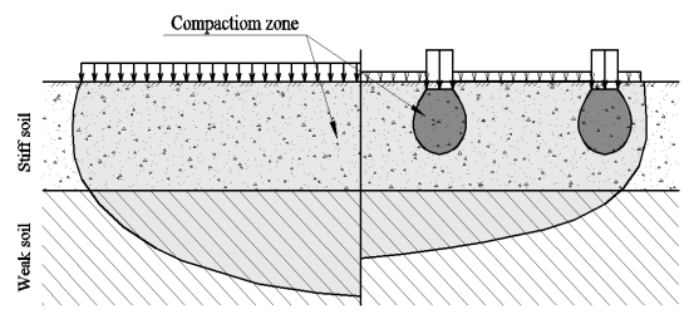

c)

Fig. 3. Rational use of DLS foundations:

a) foundations of reservoirs; b) foundations of buildings; c) weak underlying layer

\section{Experimental studies}

Complex in-situ tests were conducted to study DLS-soil bed interaction; they were aimed at revealing the features of the deformation process in clayey soil bed loaded with a stamp incorporating the damping layer. Round reinforced concrete stamp models of $1.2 \mathrm{~m}$ in diameter and $0.2 \mathrm{~m}$ in thickness were tested on the clayey soil bed composed of lacustrinealluvial soils ranging from hard to high-plastic ones with the modulus of deformation $-\mathrm{E}=8$ ... $19 \mathrm{MPa}$ (Fig. 4a) : the first stamp incorporated a flat footing, the second one - a foam polystyrene layer (PSB-15), $30 \mathrm{~mm}$ in thickness placed between the footing and the soil bed (Fig. 4b). The stamp flexibility value was equal to 0.044 after the solution of GorbunovPosadov [5], i.e. the stamps were considered to possess finite rigidity.

The soil bed of the tested stamps was equipped with the screw marks to measure vertical movements of the soil massif and membrane soil pressure cells to determine contact pressures over stamp footings (Fig. 4a) [12, 13, 14]. Movements of the bed and settlements of the stamps were measured by Aistov deflectometers mounted in the stationary benchmark station. Contact stresses were recorded in real-time mode applying Field Point device which transforms a signal received from resistive-strain sensors glued on the membrane of soil pressure cells $[15,16]$.

The stamps were loaded by a hydraulic cell through the distributive system transferring the load over four points, symmetric to the central axes. The reactive stress from the hydraulic cell was taken by the supporting frame assembled from steel beams and concrete blocks used as the static load (Fig. 4c). The load was applied stepwise after conventional stabilization - $25 \mathrm{kPa}$ for each step, when the rate of the test stamps settlements did not exceed $0.1 \mathrm{~mm}$ within the last two hours of observations [17]. Fig. 4d and Fig. 4e show photographic images of stamp making and testing.

Dependency diagrams for stamp settlement-load relation (Fig.5), diagrams of contact stresses over stamp footing (Fig.6) and isolines of vertical movements in stamp beds were 
plotted after the results of data processing obtained during static tests of the given stamps (Fig.7).

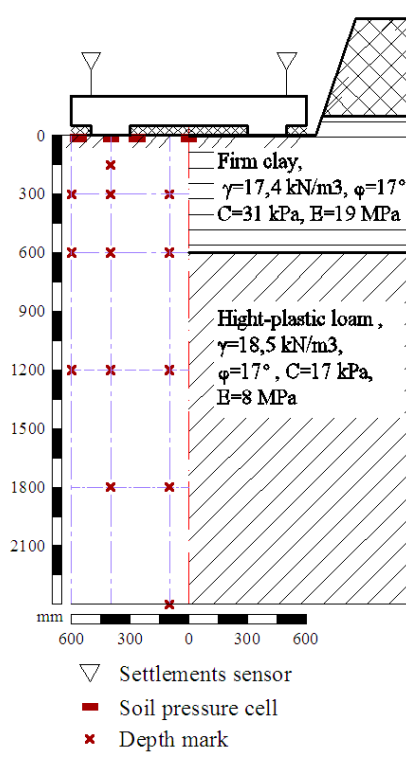

a)

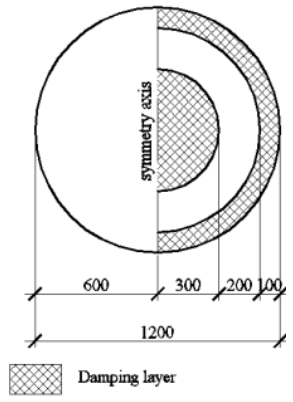

b)

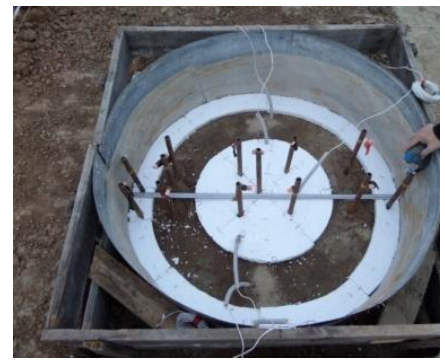

d)

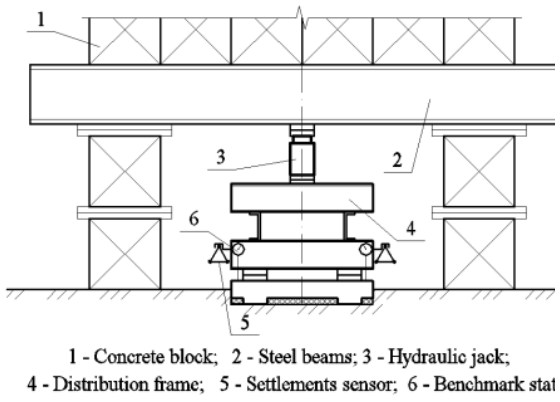

c)

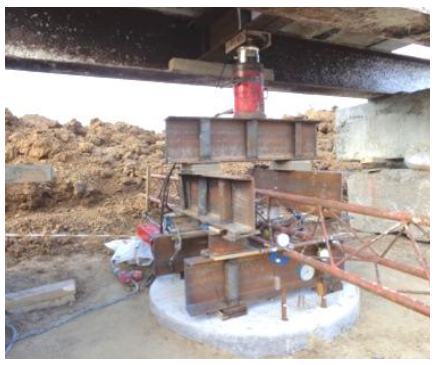

e)

Fig. 4. In-situ tests for DLS:

a) schematic illustration of sensors and geological section of the bed; b) schematic illustration of the test stamps; c) schematic illustration of the test station; d) stamp making; e) stamp testing

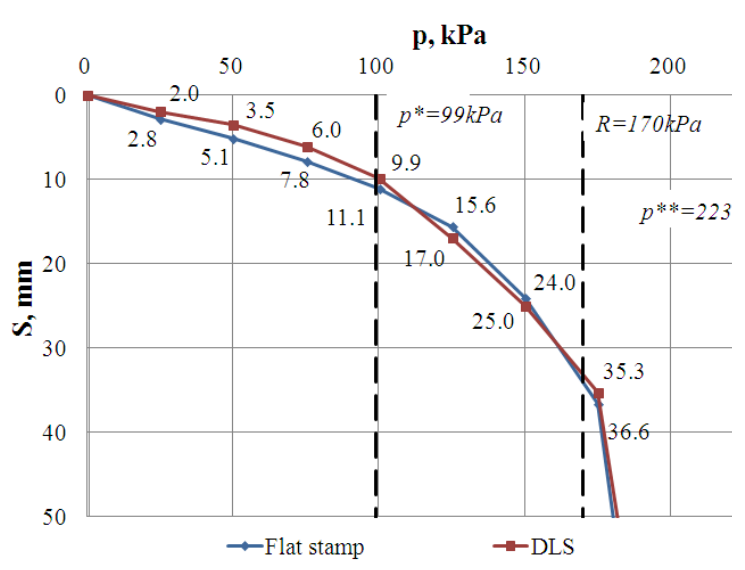

Fig. 5. Dependency diagrams for stamp settlement-load relation

One can conditionally point out two characteristic stages of stamp performance on the curves "settlement-load" (Fig. 5): a stage of "minor" quasi-linear settlements, a stage of 
"major" shear deformations. If the load upon the bed exceeds $175 \mathrm{kPa}$, soil bed failure occurs resulting in the collapsed unsettled stamp settlements.

The analysis of the test results shows that boundaries of the sites agree with the soil bed bearing capacity values:

- initial critical pressure upon the soil is evaluated by the formula after K.E.

Egorov and T.I. Finayeva [18] as for the flat round foundation:

$$
p^{*}=\left(1+\frac{\sin \varphi}{M_{0}}\right) \cdot \gamma \cdot h+\frac{\cos \varphi}{M_{0}} \cdot c=B_{0} \cdot \gamma \cdot h+D_{0} \cdot c=99 k P a
$$

- $\quad$ soil design resistance evaluated by the formula after SP [19]:

$$
R=\frac{\gamma_{c 1} \gamma_{c 1}}{k}\left[M_{\gamma} \cdot k_{z} \cdot b \cdot \gamma_{I I}+M_{q} \cdot d_{l} \cdot \gamma_{I I}^{\prime}+\left(M_{q}-1\right) \cdot d_{b} \cdot \gamma_{I I}^{\prime}+M_{c} \cdot c_{I I}\right]=170 k P a
$$

ultimate critical pressure upon the soil evaluated by the formula [20]:

$$
p^{* *}=(\gamma \cdot h+c \cdot \operatorname{ctg} \varphi) \frac{1+\sin \varphi}{1-\sin \varphi} \cdot e^{\pi \cdot \operatorname{tg} \varphi}-c \cdot \operatorname{ctg} \varphi=223 k P a
$$

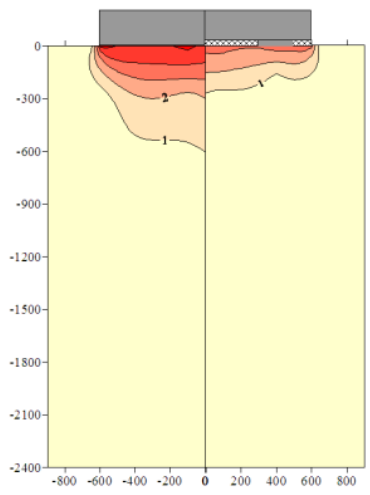

a)

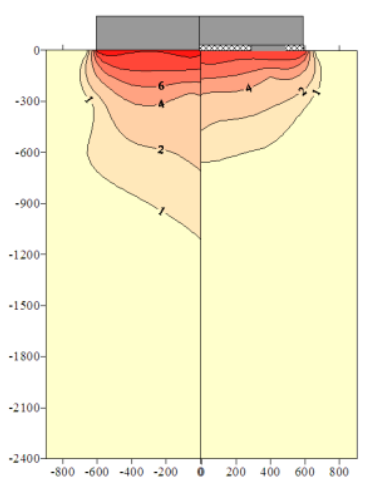

b)

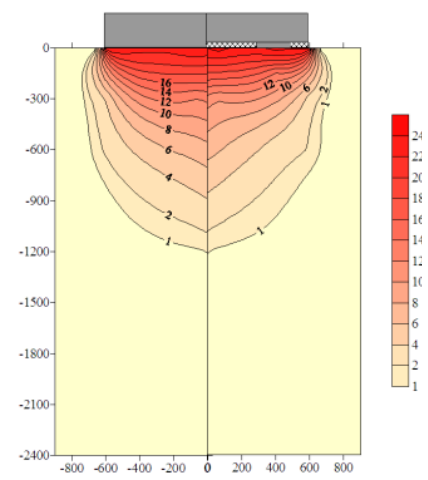

c)

Fig. 6. Isolines of vertical movements in the bed: a) $p=50 \kappa \mathrm{Pa} ; b) \mathrm{p}=100 \kappa \mathrm{Pa}$; c) $p=150 \kappa \mathrm{Pa}$;

At the first stage settlement-load dependency is close to linear if the average pressure is from 0 to $100 \mathrm{kPa}$; in here, settlements of DLS are up to $25 \%$ lower as compared to the flat stamp. At the first stage the contact pressures concentrate under the stamp edge (fig. 6); this occurs due to squeeze reduction of the foam polystyrene damping layer in the span and cantilever zones.

The analysis of layer-by-layer movements of the soil points indicates significant difference in compressibility of separate layers over the soil bed depth of the test stamps. At the first stage one can observe almost absolute loss of movements in the stamp beds at the depths of up to 0.5 of the diameter, although it is to occur at the depths of $1.0-1.5 \mathrm{~m}$ of the diameter after the theoretical solution. In here, soil movements over the central axis of the flat stamp develop to a significantly greater depth in relation to DLS. Vertical deformations of the soil bed under DLS are localized in the upper layer of firm clays, while movements in the flat stamp bed develop in the high - plastic loam subsoil. For instance, in loading with $50 \mathrm{kPa}$ deformation of the near-surface firm clay layer of 0.5 in thickness of the diameter $(600 \mathrm{~mm})$ equals to $81 \%$ from the total deformation for the flat stamp and $95 \%$ - for DLS stamp. The fact makes it possible to expand applicability of DLS in the soil conditions "stiff upper layer - weak subsoil" or "sandy cushion - weak soil" in case the loads do not exceed $\mathrm{p}^{*}$. 
At the second stage, in loads exceeding $100 \mathrm{kPa}$, DLS performance is characterized by developing ultimate limit state zones under the edges, redistribution of the load over the footing, intensive growth of stamp settlements and deformations in the weak subsoil layer. The growth of settlements is accompanied with transformation of the contact stress distribution diagram caused by extra loading of the foundation in the central and cantilever zones. On the one hand, this is due to the lack of "free movement" of the damping layer, on the other hand - development of plastic deformable zones in the soil bed under the edge. Gradual smoothing of layer-by-layer deformations in DLS bed in relation to the flat stamp is observed. Thus, the efficiency of DLS decreases at the second stage.

In excessive loading over $150 \mathrm{kP}$, intensive relative deformations in the high - plastic loam subsoil has been recorded resulting in the considerable unsettled settlements. The contact stress values over DLS footing are nearly adjusted, but with their unspecified concentration under the stamp edge. Layer-by-layer vertical movements are almost identical. Pressure increase of up to $200 \mathrm{kPa}$ (in excess of $\mathrm{R}$ ) is accompanied with continuous unsettled rise of settlements for both stamps indicating linkage of the ultimate limit state zones and loss of soil bed stability. Thus, the range of bearing loads for stamps is actually limited to the design resistance $\mathrm{R}$.

Figure 7 illustrates the dependency diagram for compressible thickness depth-tested stamp load relation. The settlement of the layer $-1 \mathrm{~mm}$ is taken as a criterion of compressible thickness depth. The given diagram shows that when loading up to $100 \mathrm{kPa}$, the depth of DLS compressible thickness is nearly twice as low as that of the flat stamp and is actually composed of the layer of firm clays.

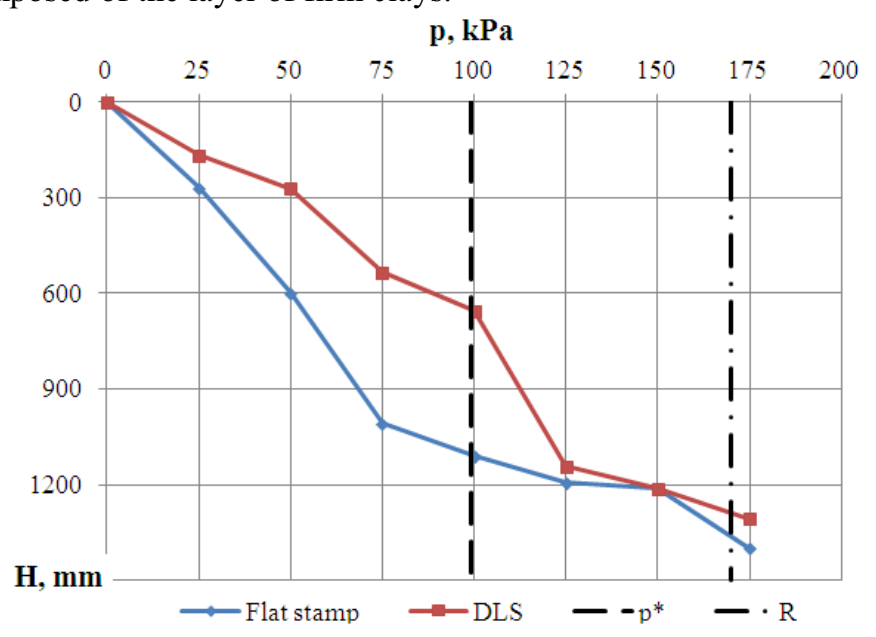

Fig. 7. Dependency diagram for compressible thickness depth-load relation

In here, the DLS diagram before $\mathrm{p}^{*}$ is close to linear, and then one can observe the "failure" accompanied with sharp increase of compressible thickness depth; it is likely caused by limit equilibrium zones appearing under the stamp edges and redistribution of load over the footing.

\section{Implementation}

The results of theoretical and experimental studies for DLS performance were used in foundation works of a block of flats - "Aquarelle" located in 9, Tavricheskaya St., Tyumen (Fig. 8). 
Initially the project involved 360 driven piles under a monolithic reinforced concrete slab. After specified calculations the bearing capacity of the pile foundation proved to be excessive in the engineering-geological conditions of the given construction site. It was decided to replace the shallow foundation with more technological one that proved to be suitable in the given conditions.

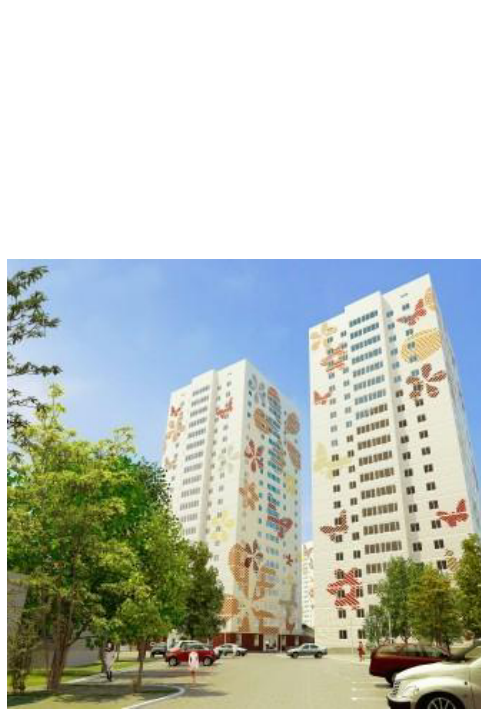

Fig. 8. General view [21] Estimated cost of foundation;
mln.rub
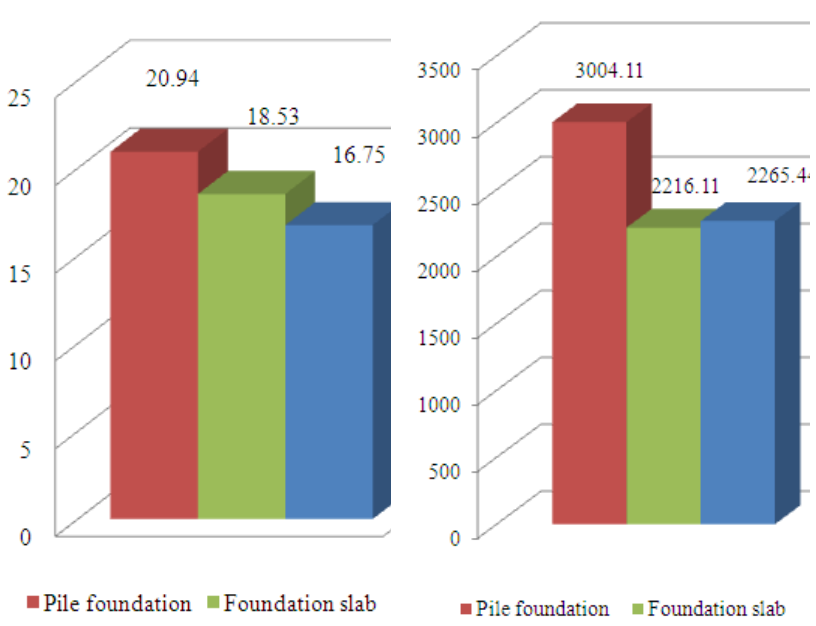

The following types of foundations were considered during design works:

- Type I - DLS composed of the rigid orthogonal strips $1.2 \mathrm{~m}$ in height focused on bearing axes of the building; the slabs $-0.8 \mathrm{~m}$ in thickness in span zones; PSB-S25 foam polystyrene damping layers placed between the slab and soil bed (Fig. 4,5).

- Type II - stationary reinforced concrete slab $1.0 \mathrm{~m}$ in thickness.

The total estimated cost for DLS reduced from 20.94 to $16.75 \mathrm{mln}$. rub (20\%); labor intensity - from 3004.11 to $2265.44 \mathrm{man} /$ hours $(25 \%)$ as compared to the slab-pile foundation. The cost of DLS appeared to be lower than that of the foundation slab, i.e. 1.8 mln. rub. of cost savings in equal labor intensity.

\section{Conclusion}

1. It has been numerically simulated that due to specified loading of the foundation it seems possible to reduce deflections and uneven settlements of the foundation slab many times and hence, the total distribution diagram of dependable bending moments.

2. The same problem shows that it is possible to achieve the analogous technical result by the damping laying placed under the foundation footing resulting in balance of uneven compressibility of the soil bed and settlements of the foundation slab. The damping layer in the foundation slab placed on the soil bed (DLS) has been analyzed and its rational applications have been highlighted.

3. Scientific research on DLS-soil bed interaction has been done on the model during the in-situ tests. The interaction stages which agree with theoretically proved strength characteristics of soil $\mathrm{p} *, \mathrm{R}$ and $\mathrm{p} * *$ have been determined. At the stage when the loads do not exceed $p *$, DLS settlements are $25 \%$ lower than those of 
the foundation slab, and the compressible thickness depth is twice as low as that of the foundation slab, the active DLS bed zone being limited to a layer of firm clays. The fact makes it possible to expand applicability of DLS in the soil conditions - "stiff upper layer - weak subsoil" or "sandy cushion - weak soil".

4. DLS has made it possible to do without 360 driven reinforced concrete piles in construction of 22 -storeyed block of flats and reduce the estimated cost of construction by $20 \%$ and labor intensity - by $25 \%$.

\section{References}

1. T. Maltseva, A. Nabokov, A. Chernykh, Procedia Engineering, 117, 239-245 (2015)

2. A. Tetior, Progressivnye konstrukcii fundamentov dlja uslovij Urala $i$ Tjumenskoj oblasti (Sredne Ural'skoe izdatel'stvo, Sverdlovsk, 1971)

3. Z. Ter-Martirosyan, Y. Pronozin, N. Kiselev,v Soil Mechanics and Foundation Engineering, 51, 157-164 (2014)

4. V. Chikishev, Y. Pronozin, V. Mironov, Internet-vestnik VolGASU. Ser.: Politematicheskaja, 20 (2012)

5. M. Gorbunov-Posadov, T. Malikova, V. Solomin, Raschet konstrukcij na uprugom osnovanii (Strojizdat, Moscow, 1984)

6. SP 22.13330.2011 Osnovanija zdanij i sooruzhenij. Aktualizirovannaja redakcija SNiP 2.02.01-83*. Moscow, (2011)

7. M. Abelev, Avarii fundamentov promyshlennyh i grazhdanskih sooruzhenij. FAOU DPO GASIS, (2011)

8. L. Dimov, Geotehnika, 1, 4-8 (2015)

9. G. Boldyrev, S. Boldyrev, Materialy Mezhdunarodnoy nauchno-tekhnicheskoy konferentsii «Sovremennye problemy fundamentostroeniya (2001)

10. M. Dubina, V. Tselitsom, M. Chukhlatyy, Materialy Mezhdunarodnoy konferentsii «Geotekhnicheskie problemy stroitel'stva krupnomasshtabnykh i unikal'nykh ob"ektov»» (2004)

11. V. Krutov, E. Sorochan, V. Kovalev, Fundamenty melkogo zalozhenija : Racional'nye konstrukcii i tehnologii ustrojstva (ASV publ., 2009)

12. A. Golli, Metodika izmerenija naprjazhenij i deformacij v gruntah: uchebnoe posobie (LISI, Leningrad, 1984)

13. Ju. Murzenko, Jeksperimental'nye issledovanija inzhenernyh sooruzhenij: materialy ko II simpoziumu, Novocherkassk (1999)

14. D. Baranov, Rukovodstvo po primeneniju prjamogo metoda izmerenij davlenij v sypuchih sredah i gruntah (CNIISK im. Kucherenko, Moscow, 1995)

15. Z. Ter-Martirosyan, Y. Pronozin, M. Stepanov, Soil Mechanics and Foundation Engineering, 49-4, 119-123 (2012)

16. A. Kraev, Nauchno-tehnicheskij vestnik Povolzh'ja, 5, 221-224 (2013)

17. GOST 20276-99. Grunty. Metody polevogo opredelenija harakteristik prochnosti i deformiruemosti, Moscow (2000)

18. K. Egorov, T. Finaeva, Osnovanija, fundamenty i mehanika gruntov, 6, 26-27 (1984)

19. SP 22.13330.2011 Osnovanija zdanij i sooruzhenij. Aktualizirovannaja redakcija SNiP 2.02.01-83*. Moscow (2011)

20. Z. Ter-Martirosjan, Mehanika, gruntov (ASV Publ., Moscow, 2005)

21. Company Group "TIS". Available at: http://ttis.ru/objects/akvarel (accessed 12 May 2016) 